\title{
Modelling tools for quantitative evaluations on the Versilia coastal aquifer system (Tuscany, Italy) in terms of groundwater components and possible effects of climate extreme events
}

\section{Strumenti modellistici per una caratterizzazione quantitativa del sistema acquifero costiero della Versilia e per valutare i possibili effetti legati agli eventi climatici estremi}

\author{
Matia Menichini, Marco Doveri
}

Riassunto: La piana costiera della Versilia è sede di un importante acquifero strategico per il fabbisogno idrico. Come tutti gli acquiferi costieri risulta particolarmente vulnerabile al fenomeno dell'intrusione marina che può essere amplificato non solo dal sovrasfruttamento della risorsa, ma anche per gli effetti legati ai cambiamenti climatici, fra i quali l'aumento del numero di eventi estremi. Per una gestione ottimale di tale preziosa risorsa, finalizzata alla sua salvaguardia sia in termini quantitativi che qualitativi, è necessaria una conoscenza adeguata del sistema acquifero mediante lo sviluppo di modelli idrogeologici concettuali e matematici. Il modello idrogeologico concettuale è stato definito sulla base di un approccio multidisciplinare integrato che ha previsto l'elaborazione di dati stratigrafici, idrogeologici e geochimiciisotopici. Successivamente sono stati realizzati modelli matematici di flusso delle acque sotterranee mediante il codice di calcolo ModFlow e interfaccia grafica Groundwater Vistas, successivamente trasferiti sulla piattaforma Freewat. I modelli sviluppati hanno permesso di acquisire ulteriori conoscenze su tale sistema acquifero, nonché di individuare e, laddove possibile, quantificare le componenti in gioco ed i principali processi in atto, fra i quali il fenomeno dell'ingressione marina. Un'importante componente

Keywords: Versilia, coastal aquifer modelling, groundwater management, climate extreme events.

Parole chiave: Versilia, modellizzazione di acquiferi costieri, gestione delle acque sotterranee, eventi climatici estremi.

\section{Matia MENICHINI 奉”}

Institute of Geoscience and Earth Resources

National Research Council of Italy

email: matia.menichini@igg.cnr.it

\section{Marco DOVERI}

Institute of Geoscience and Earth Resources

National Research Council of Italy

email: doveri@igg.cnr.it

Ricevuto/Received: 18 September 2020-Accettato/Accepted: 28 September 2020 Pubblicato online/Published online: 30 September 2020

This is an open access article under the CC BY-NC-ND license:

http://creativecommons.org/licenses/by-nc-nd/4.0/

(C) Associazione Acque Sotterranee 2020 di alimentazione, caratterizzata da acqua di buona qualità, risulta quella che dal Fiume Versilia nella zona pedemontana si infiltra nel conoide di questo fiume. Questa componente sembra essere in grado di garantire una relativa protezione della falda acquifera contro l'ingressione marina, tuttavia alcuni settori durante la stagione estiva registrano depressioni piezometriche che tendono ad espandersi e a spostarsi verso la costa favorendo il processo di intrusione di acqua di mare. Queste problematiche possono essere amplificate dagli eventi piovosi estremi che avvengono frequentemente nell'area delle Alpi Apuane. L'ingente quantità d'acqua che rapidamente defluisce a mare attraverso i fiumi durante tali eventi costituisce di fatto una mancata ricarica dell'acquifero. Come conseguenza, l'azione di mitigazione verso l'intrusione marina svolta dalla componente da conoide può esser decisamente ridotta. Basandosi sul bilancio del modello numerico e considerando un recente evento piovoso estremo accaduto nell'area Apuano-Versiliese è stato possibile eseguire considerazioni quantitative sui possibili effetti di questi regimi climatici sul sistema acquifero. I risultati suggeriscono che gli eventi piovosi estremi rappresentano una concreta minaccia per l'acquifero costiero, il quale nei prossimi decenni potrebbe esser sempre più interessato dall'intrusione salina. Data la dipendenza delle attività antropiche locali dalle acque sotterranee, azioni lungimiranti di gestione idrica (es. la ricarica assistita degli acquiferi) sono fortemente raccomandate per mitigare suddetti effetti climatici

\footnotetext{
Abstract: : The Versilia coastal plain hosts an important and strategic aquifer for water supply. Like all coastal aquifers, it is particularly vulnerable to the saltwater intrusion, which can be amplified not only by fresh water over-exploitation, but also by the effects of climate change, including the increase of extreme events. For an optimal management of this precious resource and for its protection both in quantitative and qualitative terms, an adequate knowledge of the aquifer system is necessary through the development of conceptual and mathematical bydrogeological models. The conceptual hydrogeological model was defined on the base of an integrated multidisciplinary approach with the elaboration of stratigraphic, hydrogeological and geochemical-isotopic data. Subsequently, groundwater flow mathematical models were created using the ModFlow code and Groundwater Vistas like graphical interface, subsequently transferred to the Freewat open platform. The models enabled acquiring further knowledge about this aquifer system and to identify and, where possible to quantify, the main processes and groundwater components involved, including the seawater ingression. An important groundwater component, both in terms of water quantity and quality,
} 
resulted widespread in the fan of the Versilia River and mainly fed by the river itself in the foothill zone. Although this component seems to be able to guarantee relative protection against marine ingression, in the summer season some piezometric depressions tied to groundwater exploitation tend to expand and move towards the coast, thus favouring the seawater intrusion process. These issues can be amplified by the extreme rainy events that frequently occur in the Apuan Alps region. The buge quantity of water that quickly flows by the river up to the sea during extreme events represents a lack of feeding respect to the aquifer, and consequently the mitigation role of the fan component towards seawater intrusion can be significantly weakened. Thanks to the water budget achieved by numerical model and considering real extreme events recently occurred in the Apuan-Versilian region it was possible to make considerations about possible effects these climate regimes on the aquifer system. As outcomes, we concluded that extreme events as those occurred in the area in the past, and awaited more frequently in the future, represent a concrete threat for the coastal aquifer system that over next decades could suffer more and more seawater intrusion. Given the reliance of local human activities on groundwater, far-sighted actions of water management (e.g. managed aquifer recharge) are recommended for mitigating such as climate effects.

\section{Introduction}

Water use has been increasing worldwide by about $1 \%$ per year since the 1980s, driven by a combination of population growth, socio-economic development and changing consumption patterns (WWAP 2019). Global water demand is expected to continue increasing at a similar rate until 2050, accounting for an increase of 20 to $30 \%$ above the current level of water use (Burek et al. 2016), mainly due to rising demand in the industrial and domestic sectors (OECD 2012; Burek et al. 2016; IEA 2016). Globally, more than 2 billion people depend on groundwater for their daily water supply, being the most important in terms of quantity and quality for drinking water (Hiscock 2011; Baoxiang and Fanhai 2011). In fact, the usage of surface water resources is diminishing, most of them being polluted or of poor-quality due to human activities, urban spreading and land use evolution (Delpla et al. 2009). As consequence, groundwater nowadays represents the main resource exploited for human consumption, industrial activity and irrigation. On the other hand, unlike surface water, groundwater bodies are not yet properly studied, quantitative information being scarcely available in most of cases (Doveri et al. 2017), in particular concerning the effects of anthropic pressure and climate change, especially extreme events. In this context, coastal aquifers deserve attention because they are widely exploited, frequently even over-exploited, and sensitive to climate change. Coastal zones, in fact, contain some of the most densely populated areas and have an average population density of about 80 persons per sq. $\mathrm{km}$, which is twice the world's average population density (Kantamaneni et al. 2017). The excessive withdrawal of groundwater favours the marine intrusion with consequent depletion in the available fresh groundwater resources in coastal areas (Werner et al. 2013; Alfarrah and Walraevens 2018). Inappropriate management of coastal aquifer may lead to its destruction as a source of freshwater much earlier than other aquifer not connected to the sea. To face these problems and for the protection of this precious resource it is necessary an optimal management that can be pursued only through a detailed knowledge of aquifer systems. The aim of this paper is to define a reliable hydrogeological conceptual model based on a multidisciplinary and integrated approach on the basis of which to realize a flow numerical model in order to have tools for a correct management and safeguard of this precious resource, as well as to evaluate the possible effects of climate change, in particular the effects of extreme events.

\section{Geological and hydrogeological setting}

The study area is located in the northwestern part of Tuscany (Central Italy) and it concerns the narrow coastal plain eastward delimited by the Apuan Alps and encompassed between the Baccatoio ditch to South and the Carrione River to North (Fig. 1).

The Versilian plain belongs to the Viareggio Basin (Mariani and Prato 1988; Pascucci 2005), an extensive tectonic depression that originated from the Upper Miocene following the Apennine orogenesis (Conti et al. 2009). The quaternary evolution of the Versilia plain is the subject of specific studies for the interval between the Tyrrhenian transgression of the Upper Pleistocene (80,000 years ago) and the Holocene (Federici 1993). This period includes the last great Würmian glaciation and it is characterized by a continuous alternation

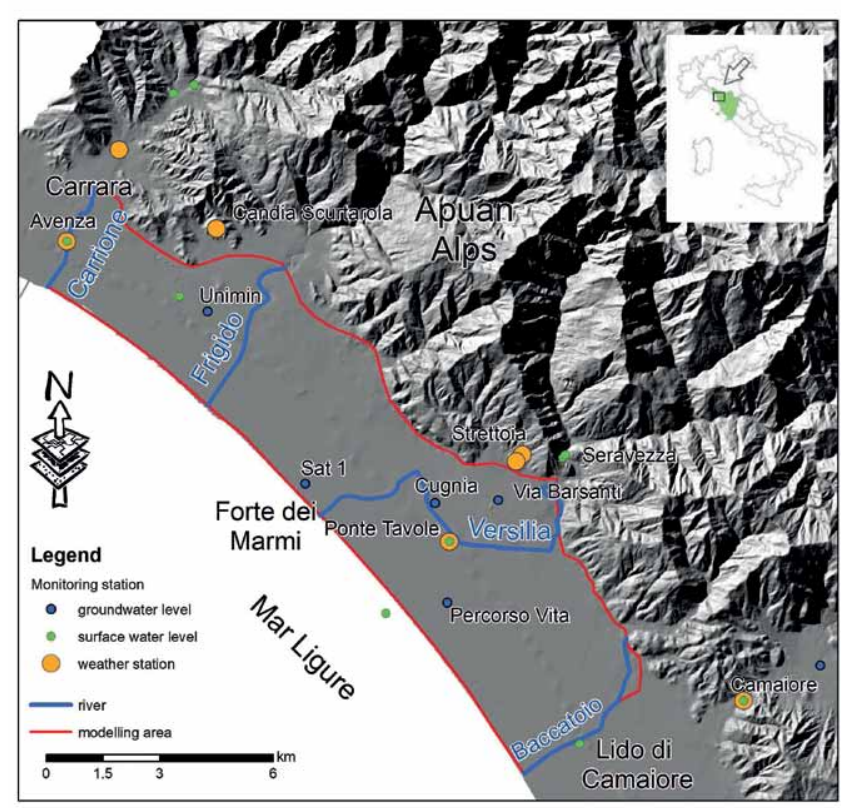

Fig. 1 - Location of study area, modelling area and monitoring station (data available http://www.sir.toscana.it/).

Fig. 1 - Ubicazione dell'area in studio, area del modello e stazioni di monitoraggio (dati disponibili sul sito: http://www.sir.toscana.it/). 
of climatic oscillations with consequent alternation of transgressive and regressive marine phases. The aquifer system is characterized by the alternation of incoherent continental, marine-transitional and marine deposits (Da Prato et al. 2015; Menichini et al. 2018 and references therein). The alternating of various degrees of primary permeability involves the presence of aquitards, aquicluds and aquifers, thus resulting in a multilayer aquifer system. The knowledge related to this aquifer is based on numerous hydrogeological works of literature (Giardi et al. 1983, Duchi and Ferrari 1984; Musetti 1985; Ferrari et al. 1987; Salvatori 1994; Salvatori 1997; Tabbì 1999; Giuntini 1999; Tessitore 2002; Doveri 2004; Pranzini 2004, Regione Toscana 2008; Da Prato et al. 2011; Menichini 2012; Da Prato et al. 2015; Menichini et al. 2018). In the foothill sector, the deposits of coastal aquifer are locally related to fractured hydrogeologic structures of the Apuan Alps (Menichini et al. 2016; Doveri et al. 2019). In particular, the aquifer of the plain could be in connection with carbonate hydrogeological complexes characterized by high permeability due to fracturing and karst phenomena (e.g. metamorphic carbonate series consisting of marbles, dolostones and cherty meta-limestones or tectonic breccia like Calcare Cavernoso).

\section{Materials and methods}

In order to define the hydrogeological conceptual model a multidisciplinary and integrated approach involving geological-stratigraphic, hydrogeological, isotopic, and geochemical disciplines was used. For geological-stratigraphic elaboration, the stratigraphic data available on Underground and Water Resources Database (BDSRI, available online at http://www.regione.toscana.it/-/banche-dati-sottosuolo) were used to delineate the geometry and thickness of the various hydrogeological horizons constituting the aquifer system. Once delineated the hydrostructural model, all stratigraphic information was re-processed with the "Groundwater Modelling Software" for 3D reconstruction and calculation of the volume for each horizon. A specific hydraulic conductivity values was attributed to each horizon as a function of lithotype data and considering the results of pumping tests that we performed. Piezometric maps elaborated by some authors in the past years (Da Prato et al. 2015) were analysed in order to identify the main flow directions, the main feeding components, the relationship groundwater-surface water, and piezometric minima with negative values. All geochemical and isotopic data produced by the authors in a PhD study (Menichini 2012) were further elaborated in order to achieve information on the hydrodynamic behaviour and physical-chemical processes, including those linked to the marine ingression. Furthermore, the main inflow and outflow components were evaluated for the studied coastal aquifer. An average annual precipitation was calculated based on the daily precipitation data recorded in the period 1997-2016 at the weather stations of Camaiore, Ponte Tavole, Carrara and Viareggio (Fig. 1), which belong to the monitoring network managed by the Regional Hydrological Sector (http://www. sir.toscana.it/). Evapotranspiration was estimated using the formula of Thornthwaite and Mather (1957) based on monthly average temperature. The latter was calculated on the basis of the daily average temperatures of Ponte Tavole station, the only station with a sufficient recording period (1998-2016). Based on average precipitation and evapotranspiration the effective rainfall was calculated. Based on acclivity, land use and outcropping lithologies, a different coefficient of potential infiltration (C.I.P.) was applied to the value of the assessed effective rainfall in order to estimate effective infiltration value. In particular, 5 main areas with different C.I.P. were identified: i) anthropized areas (20\%); ii) areas where horizon characterized by fine lithologies (mainly silt and clay) outcrops $(30 \%)$; iii) areas where horizon mainly representative of alluvial fan deposits outcrops (50\%); iv) areas where coastal sandy deposits outcrop (70\%); v) a transition area $(60 \%)$. To calculate the quantitative of groundwater withdrawn by wells, all the information reported in the BDSRI were acquired (e.g. number, location of well, pumping rate). Moreover, in the database the information regarding the well use and withdrawal are very lacking; so, basing on the few information available and by crossing the well location with the land use (urban areas, industrial areas, agricultural areas, and tourist activities ...) it was possible to associate a specific use for each well. In order to estimate the water consumption for agricultural and industrial use, data provided by CIBIC (Interdepartmental Center of Bioclimatology) and IRPET (Regional Institute of Economic Planning of Tuscany), available on the website of the Regional Hydrological Sector, were consulted. For the abstractions linked to tourist activities, whose use is mainly concentrated in the period April-September, there are no direct data, nevertheless they were estimated considering the average water consumption necessary for these types of activities. Starting from the hydrogeological conceptual model, numerical flow models in steady state condition were developed using MODFLOW-2005 code (Harbaugh 2005) and Groundwater Vistas like graphical interface. Successively, the models were transferred in FREEWAT, open source and public domain GIS-integrated modelling environment for the simulation of groundwater quantity and quality (Rossetto et al. 2017; Rossetto et al. 2018). The procedure for defining the mathematical model with the help of the graphical interface provides a series of operations starting from the implementation, calibration and then runs of the model. The first phase of the implementation consisted in the definition of the geometries using layers and cells. The hydraulic properties were attributed to each cell on the basis of the geological model realized whereas the main inflow and outflow components of the aquifer system were mathematically represented by specific boundary conditions. To calibrate the model, the "trial and error adjustment" method was used, using as calibration target the average values measured in the piezometric campaigns of September 2008 and April 2009, as well as the average values recorded by the continuous monitoring stations located in the area of interest. 


\section{Results and discussion Conceptual model}

The hydrostratigraphic elaboration highlights the multilayer type of the aquifer system due to the alternation of sandy-gravelly permeable layers and silty and clayey deposits with low and very-low permeability (Fig. 2). Specifically, three main aquifer horizons consisting mainly of sand and gravel were identified. Starting from the top, the first aquifer is hosted in the shallow sand bodies of marine origin and lies above an impermeable-semipermeable layer, extended on almost the entire studied area and characterized by variable thickness. In the coastal area it has a maximum thickness of $30 \mathrm{~m}$, which tends to decrease going inland. In some sectors, it is directly in contact with the alluvial fan, hosting another important aquifer made predominantly by gravels and subordinately by silts and sands. This has a thickness that varies from a few metres to over 30 metres and it is mainly limited to the inner foothills area. Going downwards the second important aquifer, extended on whole studied area, is made predominantly by gravels, sands and silts. Its thickness varies from a few metres in the western areas up to over 30 metres in the most inland sector. The limited thickness and the lack of continuity of low permeability layers allow locally a direct connection between different permeable horizons, giving to the system a monolayer character. As evidenced by both water level data and hydrogeochemical data processing, the hydraulic connection between the aquifer layers is likely present throughout the aquifer system, also probably due to the presence of many multi-screened wells. Taking into account grainsize of hydrostratigraphic model, as well as data from pumping tests, the hydraulic conductivity of permeable horizons is variable from $10^{-3} \mathrm{~m} / \mathrm{s}$ to $10^{-4} \mathrm{~m} / \mathrm{s}$.

Piezometric contours, elaborated both in wet and dry season, highlight that groundwater flow from the upper zone of the Versilia River alluvial fan is an important feeding component toward the coastal plain (Fig. 3). There are also minor input components from the secondary fans of minor rivers. On the base of the piezometric surface morphology and the transmissivity value of $1.4 \mathrm{E}^{-02} \mathrm{~m}^{2} / \mathrm{sec}$ obtained by a pumping test performed in the foothill sector of the Versilia fan, the groundwater flow rate in the alluvial aquifer was evaluated to be closed to $0.4 \mathrm{~m}^{3} / \mathrm{s}$ and $0.2 \mathrm{~m}^{3} / \mathrm{s}$, for high level and low level conditions, respectively. In dry season (September 2008) three extensive piezometric minima with negative values are observed; two in the medium-upper sectors of the plain, at north; the third in southern coastal sector, where a dewatering pumping system is located. The latter minima maintains also in the wet season, although with a smaller extension.

$\mathrm{Ca}-\mathrm{HCO}_{3}$ water samples with low salt content are observed in the foothills, while the samples collected in the coastal area have $\mathrm{Ca}-\mathrm{HCO}_{3}$ composition only at low depths (Fig. 4c). Among $\mathrm{Ca}-\mathrm{HCO}_{3}$ waters some samples have a higher sulphate content that could be indicative of a feeding component by water flowing in the cavernous limestone (Figs. $4 \mathrm{a}$ and 4b), whose local springs are characterized by $\mathrm{Ca}-\mathrm{SO}_{4}$ facies (Menichini et al. 2016). In the coastal area, there are also waters belonging to the chemical facies $\mathrm{Na}-\mathrm{Cl}-\mathrm{HCO}_{3}$, mix$\mathrm{Cl}-\mathrm{HCO}_{3}$, mix- $-\mathrm{HCO}_{3}$ and $\mathrm{Na}-\mathrm{HCO}_{3}$ attributable to relatively prolonged interaction with rocks or ion exchange. Finally, $\mathrm{Na}$ $\mathrm{Cl}$ waters are in the coastal area at depths generally greater than $30 \mathrm{~m}$ and where important piezometric depressions cause marine ingression (Fig. 4c).

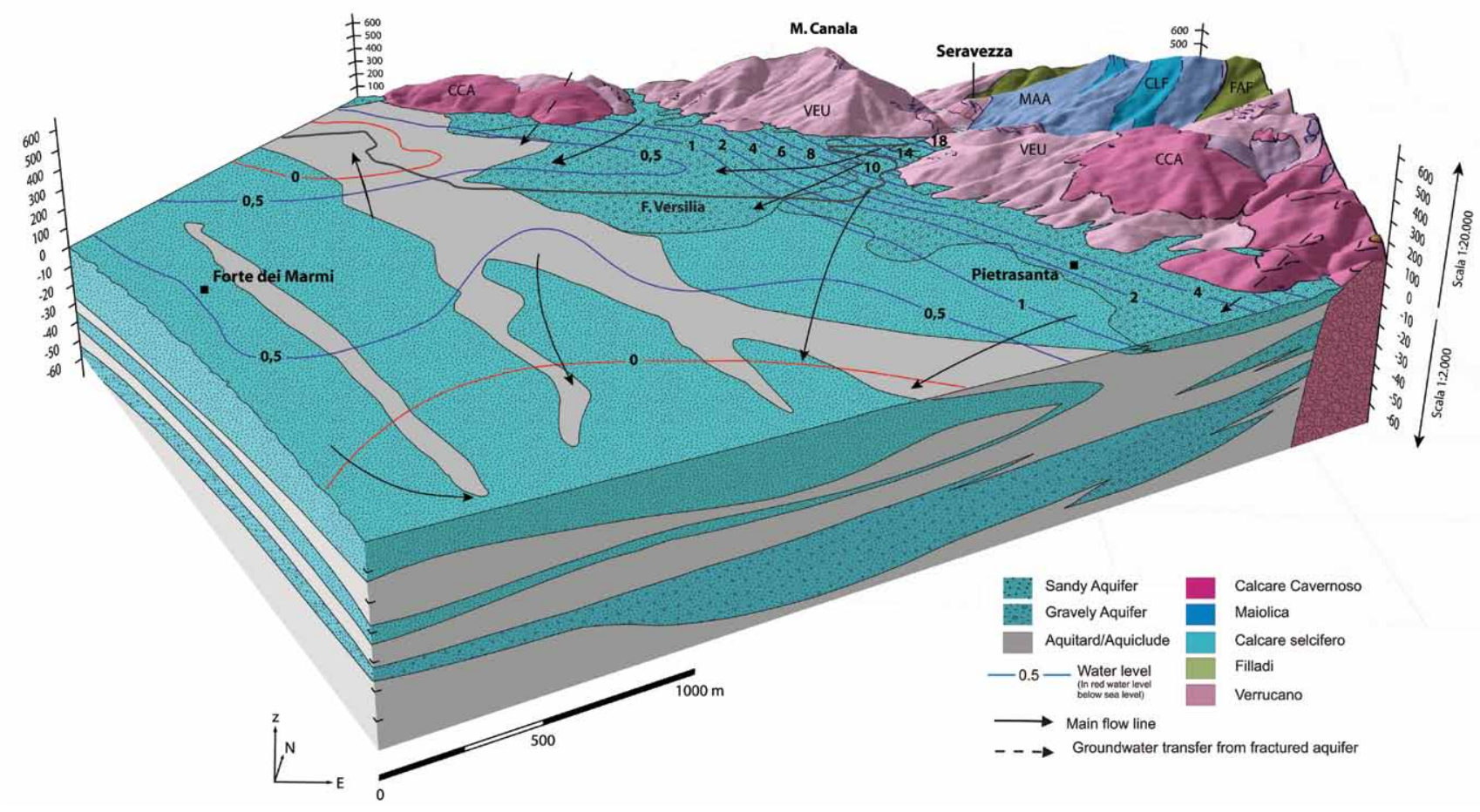

Fig. 2 - 3D bydrostratigraphic model of the Versilia aquifer system).

Fig. 2 - Modello idrostratigrafico 3D del Sistema acquifero della Versilia. 

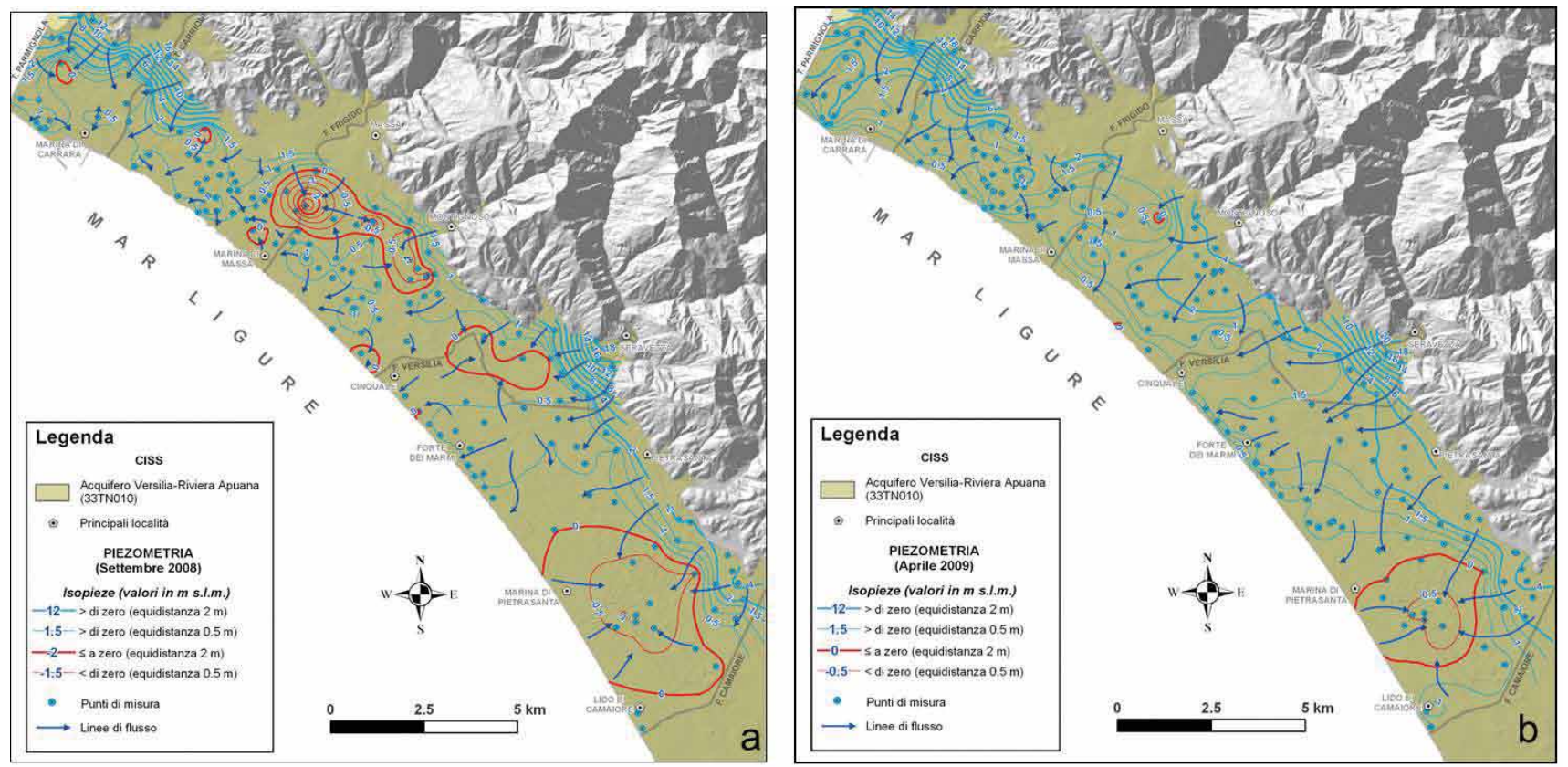

Fig. 3 - Piezometric map on: a) September 2008 and b) April 2009 (blue lines are piezometric contour lines above sea level, red lines are piezometric contour lines below sea level, blue points are the measurement points, black points are the main villages, and the blue arrows are the flow paths).

Fig. 3 - Mappa piezometrica di Settembre 2008 e Aprile 2009 (le linee blue sono le isopieze al di sopra del livello del mare, le linee rosse sono le isopieze al di sotto del livello del mare, i punti blue sono i punti di misura, i punti neri sono i principali comuni e le frecce blue sono le linee di flusso.

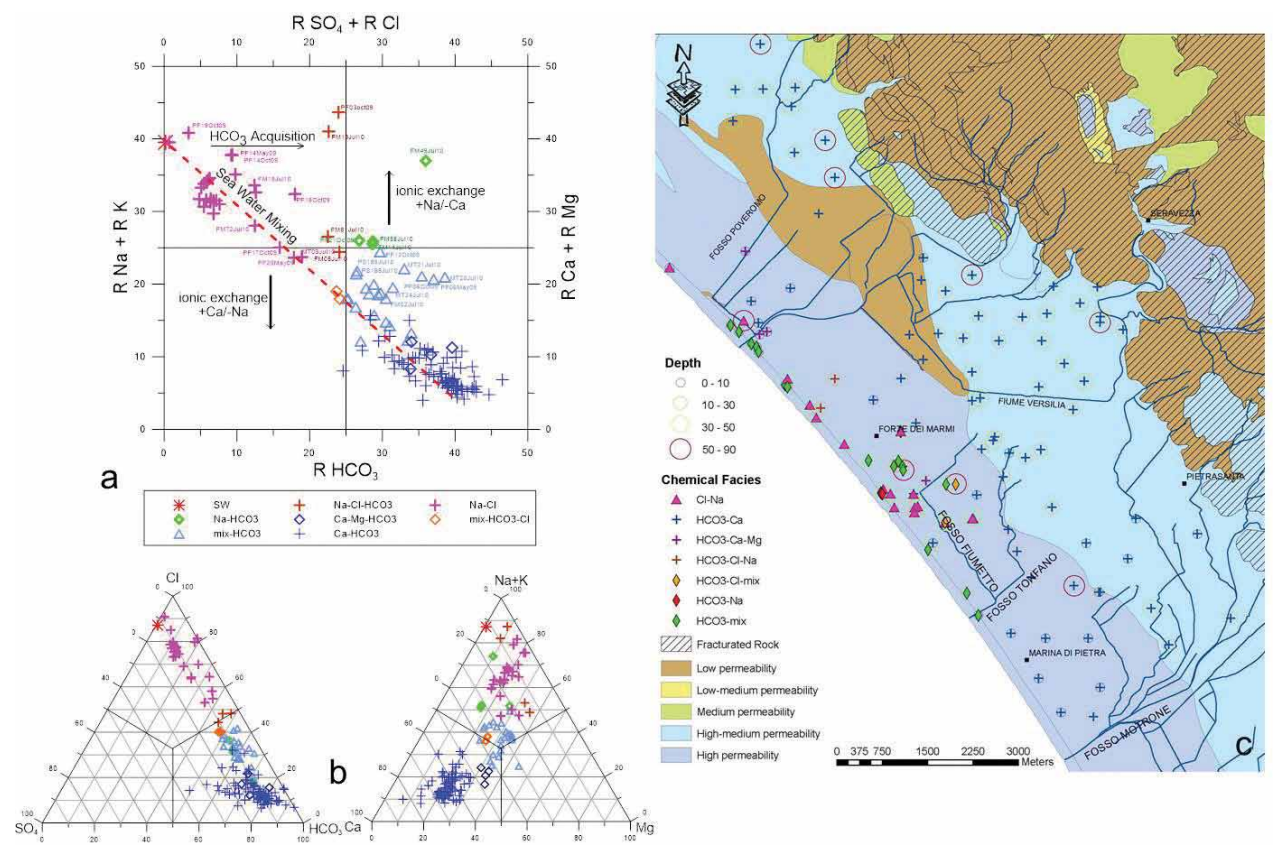

Fig. 4 - Geochemical data elaboration: a) Langelier Ludwig diagram; b) anion and cation triangular diagrams; c) map of geochemical facies.

Fig. 4 - Elaborazione dei dati geochimici: a) Diagrammi di Langelier Ludwig; b) diagrammi ternari degli anioni e dei cationi principali; c) mappa delle facies geochimiche. 
The study of ${ }^{18} \mathrm{O} /{ }^{16} \mathrm{O}$ isotopic ratio allowed to characterize the different components involved in the aquifer system of the coastal plain. In particular, a component characterized by the low isotopic ratios is recognizable starting from the upper part of the Versilia River fan up to the middle strip of the coastal plain (Fig. 5a). This component is the most important and gives a good quality to groundwater up to few hundred meters from the coastline. It seems to be able to guarantee a relative protection of the aquifer against marine ingression.
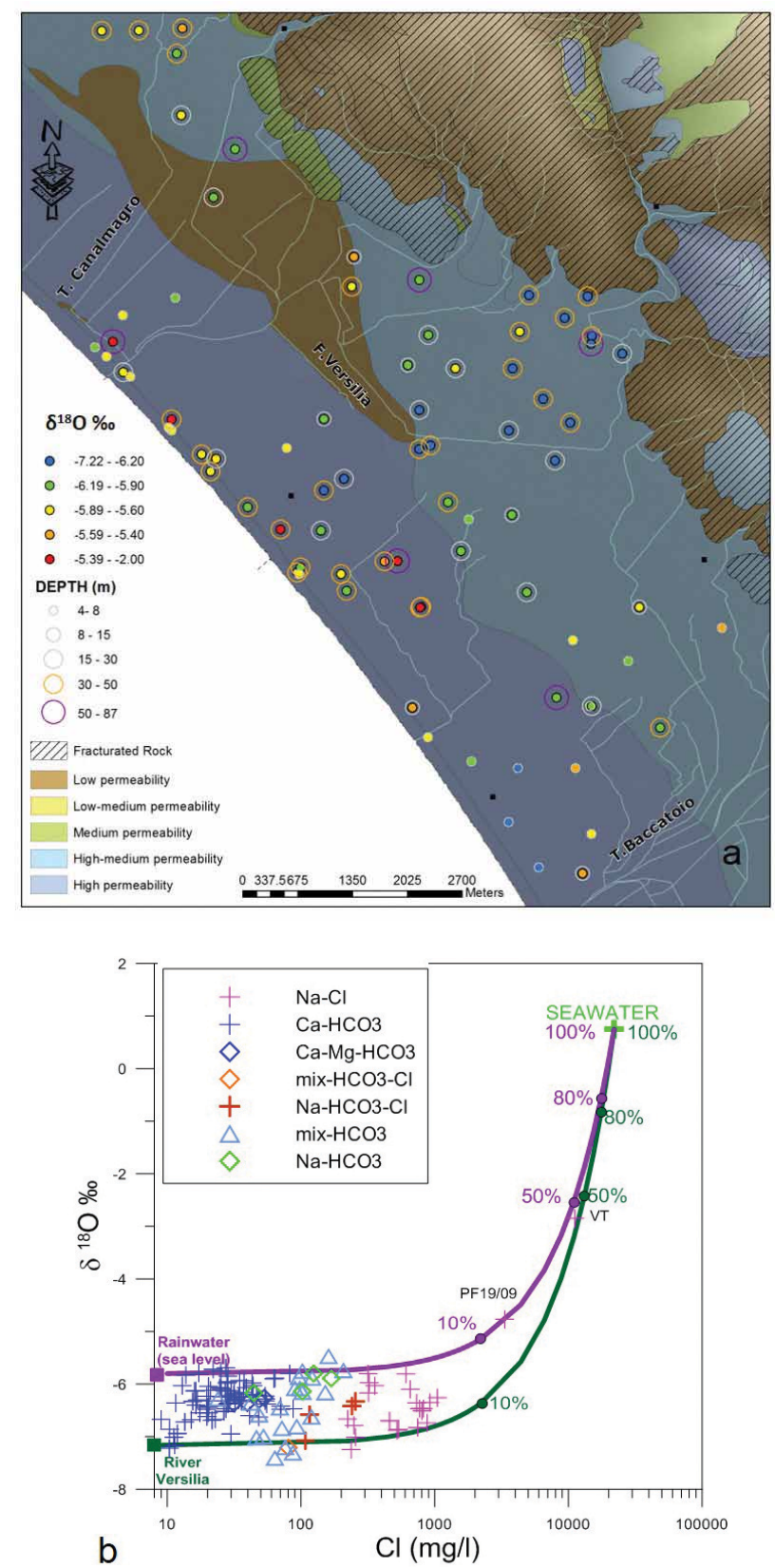

Fig. 5 - Isotopic data elaboration: a) map with isotopic ratio; b) theoretical mixing between rainwater and seawater (purple line) and rivers Versilia water and seawater (green line) and isotopic ratio of water sample.

Fig. 5 - Elaborazione dei dati isotopici: a) mappa dei contenuti isotopici; b) mixing teorico fra acqua meteorica ed acqua di mare (linea viola); mixing teorico fra il fiume Versilia e acqua di mare (linea verde) e contenuti isotopici delle acque campionate.
A further feeding component is local rainwater, which is characterized by a higher isotopic signature (Fig. 5b) typical of the Tyrrhenian coast of Italy (Doveri and Mussi 2014 and references therein). Finally, the study of isotopes confirmed the presence of the phenomenon of marine intrusion that seems to occur both directly in the aquifer and by rise along the main water courses and subsequent infiltration into the aquifer system (Fig. 5b).

\section{Numerical models}

Basing on the conceptual model previously discussed, groundwater flow numerical models were implemented. The first phase of the implementation consisted in the definition of the geometries using 3 layers and cells with dimensions of $200 \mathrm{~m} \times 200 \mathrm{~m}$ and assigning to them the hydraulic properties (Fig. 6). Specifically, in the coastal sector the first layer is the shallow aquifer made by sand with hydraulic conductivities of $60 \mathrm{~m} /$ day, the second layer is the impermeable/semipermeable interlayer (hydraulic conductivity of $1 \mathrm{~m} /$ day), whereas the third layer is the deep aquifer with hydraulic conductivities of $50 \mathrm{~m} /$ day. In the foothill sector the alluvial aquifer develops along the 3 layers with hydraulic conductivity ranging from 8 to $40 \mathrm{~m} /$ day (Fig. 6).

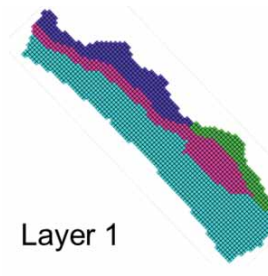

$20 \mathrm{~m} /$ day $8 \mathrm{~m} /$ day
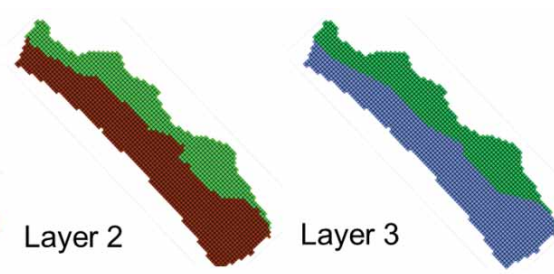

$40 \mathrm{~m} / \mathrm{day}$ $60 \mathrm{~m} / \mathrm{day}$
$1 \mathrm{~m} /$ day $50 \mathrm{~m} / \mathrm{day}$
Fig. 6 - Spatial discretization and bydraulic conductivity.

Fig. 6 - Discretizzazione spaziale e proprietà idrauliche.

The boundary conditions implemented into the model are shown in figure 7. In particular, the feeding component from rock aquifer facing to the plain and alluvial fan are represented by "General Head Boundary", whereas the "Constant Head" was used for coastline (Fig. 7a). The river were been implemented with river package using the river stage monitored by monitoring network managed by the Regional Hydrological Sector (http://www.sir.toscana.it/) (Fig. 1) and lidar image for the river bed bottom elevation and width. On the basis of the information reported in the BDSRI, in the area of interest there are about 4400 wells reported as "active". Specifically, in the area of interest were identified: i) over 3500 wells for domestic use; ii) 488 wells for industrial use; iii) 146 wells for agricultural/irrigation use; iv) 227 wells associated with tourist activities; v) 29 wells for drinking water supply. In order to estimate the water consumption for agricultural and industrial use, data provided by CIBIC (Interdepartmental 


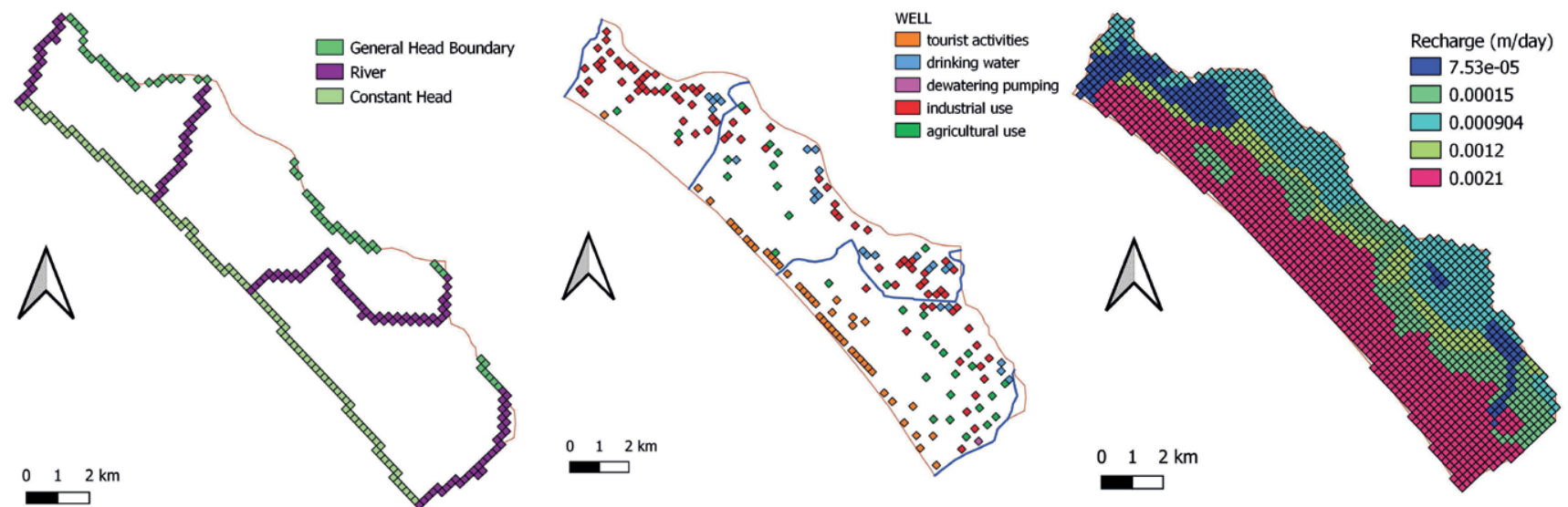

Fig. 7 - Boundary condition implemented: a) general head boundary, river and constant head; b) well; and c) recharge.

Fig. 7 - Principali boundary condition implementate: a) general head boundary, river e constant head; b) well e c) recharge.

Center of Bioclimatology) and IRPET (Regional Institute of Economic Planning of Tuscany), available on the website of the Regional Hydrological Sector, were consulted. In particular, for the area of interest, about $0.8 \mathrm{Mm}^{3} /$ year are calculated for agricultural use and about $8 \mathrm{Mm}^{3} /$ year for industrial use. For drinking water the withdrawal is about $13.6 \mathrm{Mm}^{3} /$ year (data provided by Gaia Water Service), whereas for domestic use it is estimated a very low water consumption compared to other uses. For the abstractions linked to tourist activities, whose use is mainly concentrated in the period April-September, the estimation based on the average water consumption necessary for these types of activities, given the absence of real data. To represent the high number of wells the package "Well" was used by grouping wells according to the vicinity and the type of use (Fig. 7b). Finally, in order to attribute a correct value of recharge an average annual precipitation value of about $1100 \mathrm{~mm}$ and an average value of evapotranspiration, equal to about $810 \mathrm{~mm} /$ year, were estimated, obtaining an effective rainfall of about $290 \mathrm{~mm}$ /year. By applying the different CIPs, the effective infiltration values are obtained (Fig. 7c).

In figure 8 a the location of the 42 calibration targets used for the calibration phase are shown. The results of calibration (Fig. 8b-c) point out that the groundwater model is sufficiently representative of the aquifer system, showing an absolute residual mean minor than $0.5 \mathrm{~m}$, as well as a standard error of the estimate of $0.09 \mathrm{~m}$.
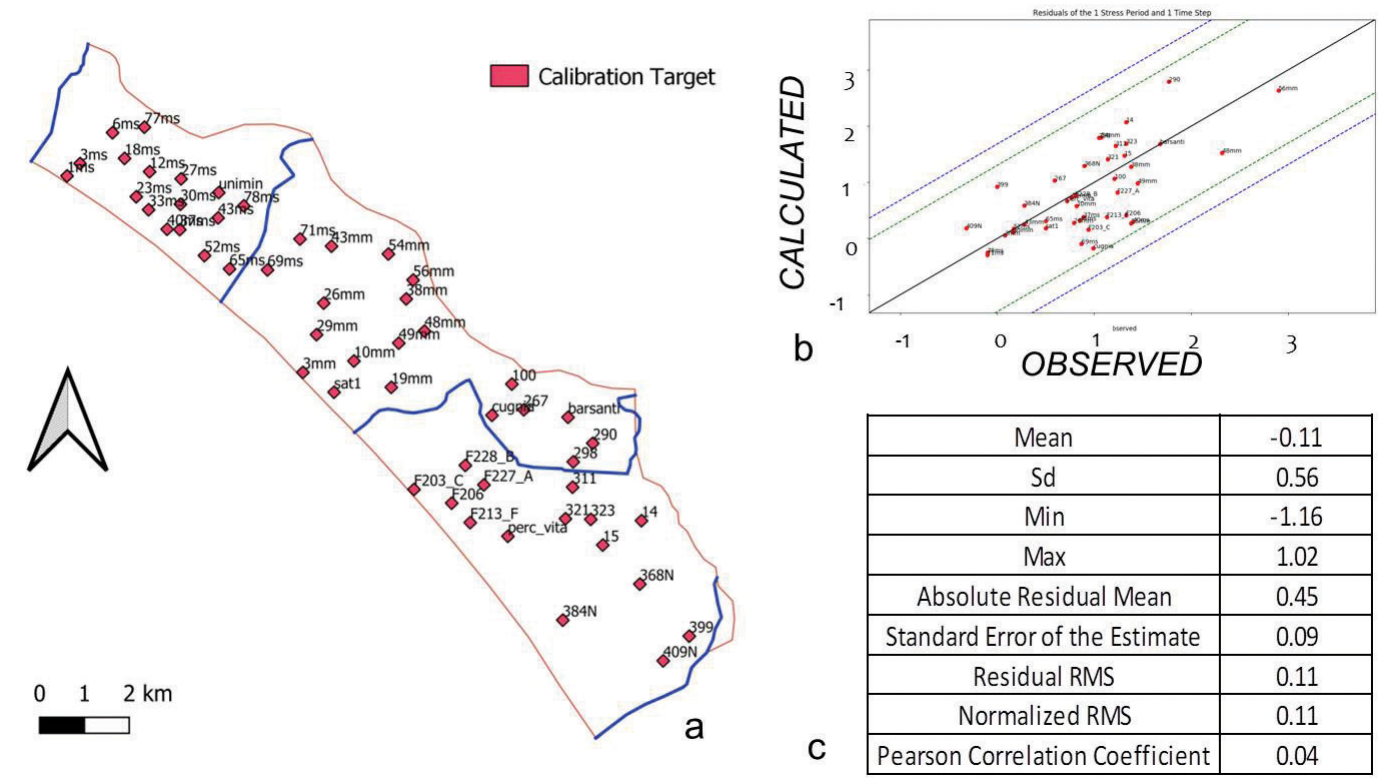

Fig. 8 -Calibration results: a) location of calibration target; b) observed vs simulated values graph; $c$ ) statistical parameter of residuals.

Fig. 8 - Risultati della calibrazione: a) ubicazione dei target di calibrazione; b) grafico valori osservati vs valori simulati; c) parametri statistici dei residui. 
In figure 9 we also report the water balance that confirms the hydrogeological conceptual model previously defined. The main input to the system is the effective infiltration that covers about $50 \%$ of the total recharge. The other half of recharge volumes derives from the river seepage and the groundwater transferred from the foothill rocky aquifers and from alluvial fans, with percentages of about $21 \%$ and $31 \%$, respectively. The water balance also confirms the presence of the phenomenon of marine intrusion, albeit of modest entity (Fig. 9).

Going more specifically in a limited area near the Versilia River, it was possible to better evaluate and quantify relationship between the river and groundwater. Specifically, it was evaluated that in this limited sector the percentage of river seepage reaches $33 \%$, with volumes of about 2.7 million $\mathrm{m}^{3} /$ year out of a total 8.5 million $\mathrm{m}^{3} /$ year of total feeding components. These data confirm as the mountain rivers and their fan bodies play a strategic role in terms of feeding for aquifers developing in plain and coastal areas. Hence, the foothill areas should receive specific attentions and actions aimed at improving the groundwater storage and protecting this precious resource (Doveri et al. 2016), also in relation to climate change and extremes. If we consider for example the extreme precipitation event occurred in November 2014 over the Carrara territory (at the northern sector of the studied area), in which in a few hours about 9 million $\mathrm{m}^{3}$ of water rained, most of this water volume was lost at sea flowing through the river. Considering that these quantities are about three times the annual Versilia River seepage calculated by the model, it is therefore possible to understand how the occurrence of these events could have substantial consequences by reducing recharge quantities for this type of aquifers. In the medium-long term the occurrence of these events alternating with drought periods could have effects of significant reduction of total storage in foothill-coastal aquifers like that of this case study, with negative consequence also in terms of the water quality because of conditions more favourable to seawater intrusion.

\section{Conclusion}

This paper concerns a hydrogeological study carried out on important coastal aquifer systems located in the Versilia area, in which high water demand is present and consequently a detailed knowledge of the same systems is necessary to optimize the groundwater resources management. The developed hydrogeological conceptual and mathematical models allowed to acquire further knowledge about the Versilia coastal aquifer system and identify the main processes in place, among which the phenomenon of marine ingression. Important feeding component extending in the Versilia River fan and characterized by good quality water seems to be able to guarantee a relative protection of the aquifer against marine ingression. However, it should be noted that during the summer season, and particularly in the Massa-Marina di Massa and Marina di Pietrasanta area, the piezometric depressions recorded in the inland sectors tend to expand and move towards the coast. This aspect projected over a significant period of years and considering also the climate change could favour the marine ingression. Thanks to the water budget achieved by numerical model and considering real extreme events recently occurred in the Apuan-Versilian region it was possible to make considerations about possible effects of these climate regimes on the aquifer system. Results highlighted that extreme events as those occurred in the area in the past, and awaited more frequently in the future, represent a concrete threat for the coastal aquifer system that over next decades could suffer more and more seawater intrusion. The huge quantity of water that quickly flows by the river up to the sea during extreme events represents a lack of feeding respect to the aquifer, and consequently the mitigation role of the fan component towards seawater intrusion can be significantly weakened. The models developed could contribute in order to define strategies and far-sighted actions of water management (e.g. managed aquifer recharge) for mitigating such as climate effects

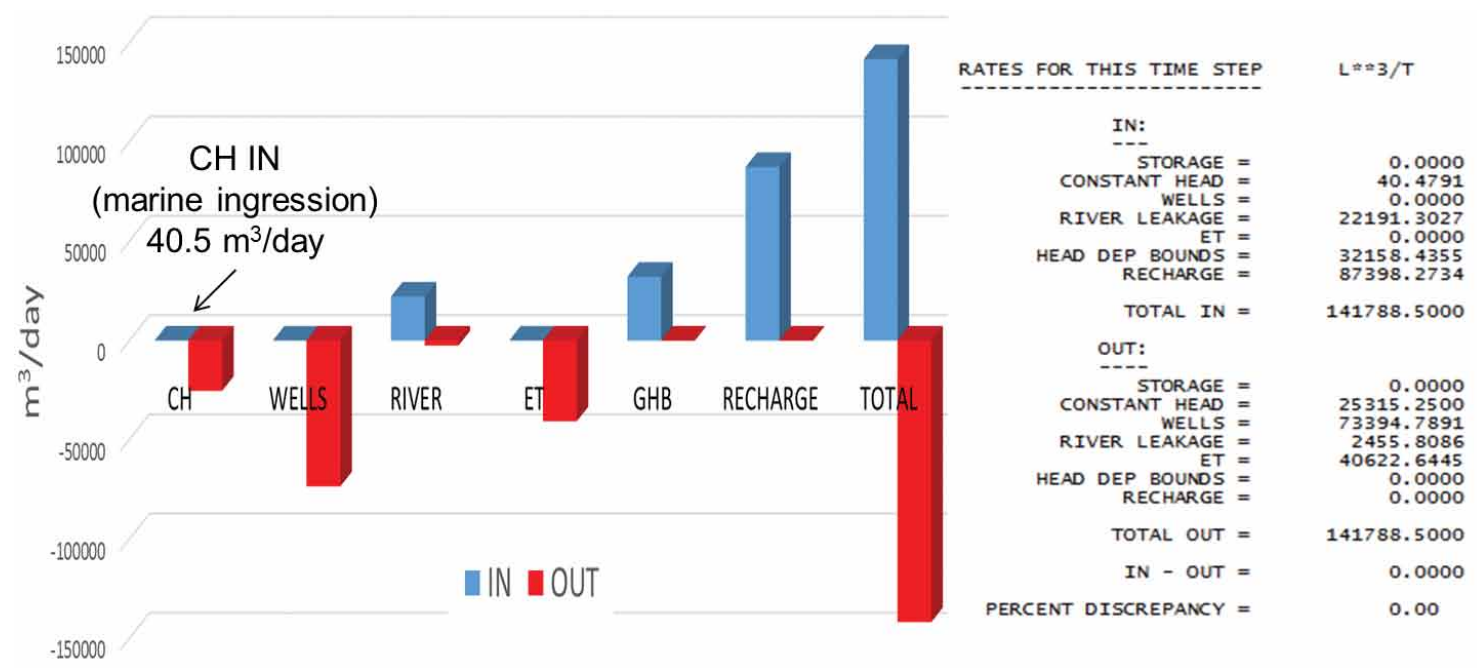

Fig. 9 - Water balance of flow groundwater model.

Fig. 9 - Bilancio di massa del sistema acquifero. 


\section{REFERENCES}

Alfarrah N, Walraevens K (2018) Groundwater overexploitation and seawater intrusion in coastal areas of arid and semi-arid regions. Water 10: 143. https://doi.org/10.3390/ w10020143.

Baoxiang Z, Fanhai M (2011) Delineation methods and application of groundwater source protection zone. In: Water Resource and Environmental Protection (ISWREP), 2011 International Symposium on Volume: 1 (IEEE Conference Publications): pp 66-69.

Bossio A, Cerrina Feroni A, Cortopassi A, Da Prato S, Ellero A, Ottria G, Zanchetta G (2008) Evoluzione paleo ambientale della piana versiliese. "Paleo environmental evolution of the Versilia plain". Giornate di Paleontologia VIII ed. - Simposio della Soc. Paleont. It. - Accademia dei Fisiocratici, Siena, pp. 13-14.

Burek P, Satoh Y, Fischer G, Kahil MT, Scherzer A, Tramberend S, Nava LF, Wada Y, Eisner S, Flörke M, Hanasaki N, Magnuszewski P, Cosgrove B. Wiberg D (2016) Water Futures and Solution: Fast Track Initiative (Final Report). IIASA Working Paper. Laxenburg, Austria, International Institute for Applied Systems Analysis (IIASA). pure.iiasa.ac.at $/ 13008 /$.

Conti P, Carmignani L, Meccheri M, Massa G, Fantozzi PL, Masetti G, Rossetto R (2009) Note Illustrative della Carta Geologica d'Italia alla scala 1:50.000, Foglio 260 - Viareggio. "Illustrative Notes of the Geological Map of Italy at scale 1:50.000, Sheet 260 - Viareggio,". pp. 145, Servizio Geologico d'Italia, Roma.

Da Prato S, Doveri M, Ellero A, Lelli M, Marini L, Masetti G, Nisi B, Raco B (2011) Caratterizzazione geologica, idrogeologica e idrogeochimica dei Corpi Idrici Sotterranei Significativi della Regione Toscana (CISS): 33TN010 "Acquifero della Versilia e Riviera Apuana"; 99MM010a "Acquifero carbonatico delle Alpi Apuane" (caratterizzazione idrogeochimica). "Geological, hydrogeological and bydrogeochemical characterization of the Significant Underground Water Bodies of the Tuscany Region (CISS): 33TNO10 "Aquifer of Versilia and Riviera Apuana"; 99MM010a "Carbonate Aquifer of the Apuan Alps" (bydrogeochemical characterization". Rapporto tecnico IGG n ${ }^{\circ} 10960$ del 30/11/2011 (Convenzione IGG/Lamma del 16/11/2010), pp. 78.

Da Prato S, Doveri M, Ellero A, Lelli M, Masetti G, Menichini M, Nisi B, Raco B (2015) Caratterizzazione geologica, idrogeologica e idrogeochimica dei Corpi Idrici Sotterranei della Regione Toscana (CIS)": 33TN010 "Corpo idrico della Versilia e Riviera Apuana". "Geological, hydrogeological and hydrogeochemical characterization of the Underground Water Bodies of the Tuscany Region (CIS)": 33TNO10 "Water Body of Versilia and Apuan Riviera". Rapporto tecnico CNRIGG $\mathrm{n}^{\circ} 11151$ del 31/03/2015 (Convenzione IGG/Lamma del 07/02/2014), pp. 15.

Delpla I, Jung AV, Baures E, Clement M, Thomas O (2009) Impacts of climate change on surface water quality in relation to drinking water production. Environment international, 35(8), 1225-1233.

Devoti S, Nisi MF, Silenzi S (2003) Caratteri geologici ed evoluzione paleogeografica della pianura versiliese. "Geological characters and paleogeographic evolution of the Versilia plain." Studi costieri, 6, 31-56.

Doveri M, Menichini M, Scozzari A (2016) Protection of groundwater resources: worldwide regulations and scientific approaches. In Threats to the Quality of Groundwater. Springer, Berlin, Heidelberg, pp. 13-30.

Doveri M, Menichini M, Provenzale A, Scozzari A (2017) Groundwater response to climate changes: examples of observed and modeled trends on Tuscany aquifers (central Italy). Atti del Convegno "XVII Giornata Mondiale dell'Acqua-"Strategie di adattamento alla domanda e alla disponibilità di risorse idriche", Accademia dei Lincei, Roma.

Doveri M, Piccini L, Menichini M (2019) Hydrodynamic and Geochemical Features of Metamorphic Carbonate Aquifers and implications for Water Management: The Apuan Alps (NW Tuscany, Italy) Case Study. Karst Water Environment, The Handbook of Environmental Chemistry, Springer, 68, pp. 209-249.
Duchi G, Ferrari R (1984) Analisi geologica e stratigrafica generale. Freatimetria dell'acquifero superficiale e analisi isoconduttive. "General geological and stratigraphic analysis. Surface aquifer freatimetry and isoconductive analysis." In Studio idrogeologico della piana versiliese. Ass. Intercom. Versilia.

Doveri M (2004) Studio idrogeologico e idrogeochimico dei sistemi acquiferi del bacino del torrente Carrione e dell'antistante pianura costiera. "Hydrogeological and hydrogeochemical study of the aquifer systems of the Carrione torrent basin and the coastal plain". Tesi di dottorato in Scienze della Terra. Università di Pisa.

Doveri M, Mussi M (2014) Water isotopes as environmental tracers for conceptual understanding of groundwater flow: an application for fractured aquifer systems in the "Scansano-Magliano in Toscana" Area (Southern Tuscany, Italy). Water 6:2255-2277

Federici PR (1993) The Versilian transgression of the Versilia area (Tuscany, Italy) in the light of drillings and rediometric data. Mem. Soc. Geol. It., 49, 217-225.

Ferrari R, Duchi G, Musetti R (1987) Studio idrogeologico della Piana Versiliese. Rilievi e indagini 1984-1986. "Hydrogeological study of the Versilian Plain. Surveys and investigations 1984-1986." Ass. Intercom. Versilia.

Giardi M, Pranzini G, Serretti L (1983) Salt water intrusion in the coastal plains of Versilia and Elba Island (Tuscany). Geol. Appl. e Idrogeol., XVIII (2).

Giuntini D (1999) Salinizzazione da cloruri delle acque sotterranee della Versilia: studio idrogeologico e idrochimico finalizzato all'elaborazione di un modello concettuale d'intrusione marina delle acque mineralizzate nell' acquifero costiero. "Chloride salinisation of groundwater in Versilia: hydrogeological and hydrochemical study aimed at developing a conceptual model of marine intrusion of mineralised water into coastal aquifers". Tesi di laurea in Scienze Geologiche, Facoltà di Scienze M.F.N., Università di Pisa.

Harbaugh AW (2005) MODFLOW-2005, the U.S. Geological Survey modular ground-water model - the ground-water flow process. U.S. Geological Survey Techniques and Methods 6-A16, 253p.

Hiscock KM (2011) Groundwater in the $21^{\text {st }}$ century - meeting the challenges. In: Anthony J, Jones A (eds) Sustaining groundwater resources: a critical element in the global water crisis, in International Year of Planet Earth, Springer, London New York, pp 207-225.

IEA (International Energy Agency) (2016) Water Energy Nexus: Excerpt from the World Energy Outlook 2016. Paris, IEA Publications. www.iea.org/publications/freepublications/publication/ WorldEnergyOutlook2016ExcerptWaterEnergyNexus.pdf.

Kantamaneni K, Du X, Aher S, Singh RM (2017) Building blocks: a quantitative approach for evaluating coastal vulnerability. Water 9 , 905. https://doi.org/10.3390/ w9120905

Mariani M, Prato R (1988) I bacini neogenici costieri del margine tirrenico: approccio sismico-stratigrafico. "The coastal neogenic basins of the Tyrrhenian margin: seismic-stratigraphic approach". Mem. Soc. Geol. It., 41, 519-531.

Menichini M (2012) A multidisciplinary approach to define the hydrogeological model of aquifer systems in the "Fiume Versilia" catchment and the adjacent coastal plain (Northwest Tuscany, Italy). Tesi di Dottorato, Università di Pisa, Scuola di Dottorato Galileo Galilei, Programma in Scienze della Terra, pp. 341.

Menichini M, Doveri M, Piccini L (2016) Hydrogeological and geochemical overview of the karst aquifers in the Apuan Alps (Northwestern Tuscany, Italy). Italian Journal of Groundwater, AS16-198: $15-23$.

Menichini M, Da Prato S, Masetti G, Doveri M, Ellero A (2017) Approfondimento e sviluppo delle conoscenze riguardanti i sistemi acquiferi regionali: modello numerico di flusso del sistema acquifero "Versilia e Riviera Apuana". "Deepening and development of knowledge about regional aquifer systems: numerical flow model of the "Versilia and Riviera Apuana" aquifer system" Relazione finale. Rapporto tecnico CNR-IGG, dicembre 2018 (Convenzione IGG/Lamma del 23/02/2017), 51 pp. 
Musetti R (1985) Studio idrogeologico di una parte della piana litoranea versiliese compresa tra marina di Pietrasanta e Forte dei Marmi. "Hydrogeological study of a part of the Versilia coastal plain between Marina di Pietrasanta and Forte dei Marmi" In: Studio idrogeologico della Piana Versiliese. Rilievi e indagini 1984-1986. Ass. Intercom. Versilia.

Nisi MF, Antonioli F, Dai Pra G, Leoni G, Silenzi S (2003) Coastal deformation between the Versilia and the Garigliano plains (Italy) since the last interglacial stage. J. of Quaternary Science, 18 (8), 709-721.

OECD (Organisation for Economic Co-operation and Development). (2012) OECD Environmental Outlook to 2050: The Consequences of Inaction. Paris, OECD Publishing. doi. org/10.1787/9789264122246-en.

Pascucci V (2005) Neogene evolution of the Viareggio Basin, Northern Tuscany (Italy). GeoActa, 4, 123-138, Bologna.

Pranzini G (2004) Studio idrogeologico del Bacino Regionale Toscana Nord. "Hydrogeological study of the North Tuscany Regional Basin" Regione Toscana, Dipartimento delle Politiche Territoriali e Ambientali, Area Difesa del Suolo e Tutela delle Risorse Idriche, U.O.C. Risorsa Idrica Interna e Marina. Relazione conclusiva.

Regione Toscana (2008) Ottimizzazione del monitoraggio della falda costiera Apuo-versiliese e formazione della banca dati. "Optimisation of Apuo-versiliese coastal groundwater monitoring and database" Bacino Regionale Toscana Nord.

Rossetto R, De Filippis G, Borsi I, Foglia L, Cannata M, Criollo R, Vásquez-Suñé E (2017) Spatial analysis and simulation tools for groundwater management: the FREEWAT platform. Italian Journal of Groundwater, AS22-293: 07 - 12.

Rossetto R, De Filippis G, Borsi I, Foglia L, Cannata M, Criollo R, Vázquez-Suñé E (2018) Integrating free and open source tools and distributed modelling codes in GIS environment for data-based groundwater management, Environmental Modelling \& Software, 107:210-230
Salvatori I (1994) La falda e le caratteristiche chimico-fisiche delle acque della Pianura Apuana. "The groundwater and the chemical-physical characteristics of the waters of the Apuan Plain". Tesi di laurea in Scienze Geologiche, Facoltà di Scienze M.F.N., Università di Pisa.

Salvatori P (1997) Studio idrogeologico della pianura versiliese compresa tra Viareggio e Forte dei Marmi, con particolare attenzione riguardo all'intrusione marina. "Hydrogeological study of the Versilia plain between Viareggio and Forte dei Marmi, with particular attention to the marine intrusion". Tesi di laurea. Dipartimento di Scienze della Terra, Università di Pisa.

Tabbì R (1999) Salinizzazione da cloruri delle acque sotterranee della Versilia: analisi idrogeologica dei meccanismi di tale salinizzazione, con particolare riguardo al ruolo dei corsi d'acqua. "Chloride salinisation of the Versilia aquifer: hydrogeological analysis of the mechanisms of this salinisation, with particular regard to the role of watercourses". Tesi di Laurea in Scienze Geologiche - Università degli Studi di Pisa, a.a. 1998-1999, $128 \mathrm{pp}$

Tessitore S (2002) Caratterizzazione idrogeologica e sviluppo di un modello numerico del sistema acquifero costiero della Versilia. " $\mathrm{Hy}$ drogeological characterization and development of a numerical model of the Versilia coastal aquifer system". Dottorato di Ricerca in Scienze della Terra GEO/05 - Università di Pisa, pp. 175.

Thornthwaite CW, Mather JR (1957) Instructions and tables for computing potential evapotranspiration and the water balance. Drexel Institute of Technology, Publications in Climatology Vol X, No. 3 , Centerton, New Jersey. 311 pp.

Werner AD, Bakker M, Post VE, Vandenbohede A, Lu C, AtaieAshtiani B, Simmons CT, Barryn D (2013) Seawater intrusion processes, investigation and management: recent advances and future challenges. Adv. Water Resour. 51, 3-26. https://doi. org/10.1016/j. advwatres.2012.03.004.

WWAP (UNESCO World Water Assessment Programme) (2019) The United Nations World Water Development Report 2019: Leaving No One Behind. Paris, UNESCO. 